\title{
THE ECONOMIC IMPACTS OF THE 2013 REFORM ON THE HUNGARIAN AGRICULTURE
}

\author{
Tamás Mizik \\ Corvinus University of Budapest, Hungary \\ tamas.mizik@uni-corvinus.hu
}

\begin{abstract}
The impacts of agricultural policies are decisive on the agricultural sector, especially in the case of the European Union's (EU) Common Agricultural Policy (CAP). The 2013 CAP reform introduced several new measures. In budgetary terms, basic payment and greening were the most significant ones. Besides, coupled supports, young farmer and small farmers scheme should be mentioned. To reveal the changes caused by these measures, the time horizon of the study is 2013-2017. Since the subsidies represent a significant part of the income generated in the agricultural sector, the basic hypothesis of the study is that the production units concerned (individual farms, private enterprises) gave economically rational answers. In practice, this means trying to fully adapt to the changes to maximize support. Based on the analysed datasets (Hungarian Central Statistical Office and Hungarian State Treasury), it became evident that farmers responded rationally: splitting up farms against capping, moving towards the lowest resistance to comply with greening, plus associating them with the extra support of coupled payments. Generational renewal is a key issue; however, the present form of young farmers scheme needs to be refined to be more effective. Small farmers scheme is a good opportunity for farmers with less than 5.5 ha and most of the concerned farmers chose well. However, there are about 6,000 farms that are too small for the standard system, while 772 farms that are too large for the small farmers scheme.
\end{abstract}

Key words: basic payment, degressivity and capping, greening, coupled support, young and small farmers scheme.

\section{Introduction}

The Common Agricultural Policy (hereinafter CAP), introduced in 1962, was the only integrated policy in Europe for a long time (EC, 2012). Its initial form was highly productive due to the needs and expectations of that time, which has caused serious problems (e.g. overproduction, expensive operation) after achieving self-sufficiency. To deal with this, first an adjustment was made, followed by 5 substantive reforms (1992, 2000, 2003, 2008 and 2013). The article analyses the impact of the measures of the most recent reform on Hungarian agriculture, which took place under the control of commissioner Dacian Ciolos.

Possible pro-active adaptation to agricultural policy changes is a key issue in the growing, European level competition. It must be aware of the different requirements and meet the eligibility criteria. This is particularly important in Hungary, as the aggregate income generated by the agricultural sector was 715.5 billion HUF in 2017 where the share of different EU supports, mostly direct payments, was nearly 60\% (423.8 billion HUF) (HCSO, 2019a). Knowing the support system and readiness to future changes to the highest possible extent are essential in case of this level of dependency.

One of the most significant innovations of the 2013 CAP reform was greening, but it is questionable how many environmental benefits it resulted with compared to its initial form. That is the reason why it has been criticized in advance. In this context, Matthews (2013) highlighted its expected low impact and competing nature with cross-compliance and agri-environmental measures. According to one of the European Court of Auditors' (ECA) study, this is essentially a further extension of cross-compliance, although that has not yet achieved the desired effect (ECA, 2008). Basically, due to the measurability problems and the causal relationship, we can call it greenwashing (Alons, 2017). It is also worth noting that compliance with greening did not require substantial efforts from most farmers (EC, 2017). For example, nearly half of the farms and $89 \%$ of the farmers are not covered by it (Greer, 2017). One of the intended aims of greening was to increase positive externality or to decrease negative externality. However, Solazzo and his fellows were able to demonstrate that it resulted in only a $1.5 \%$ decrease in greenhouse gas emissions in Italy (Solazzo et al., 2016). Due to the significant number of exceptions (Agri-Environment Scheme, organic production, farm size, etc.), as well as the cause-and-effect problems, the environmental impact was lower than planned.

Degressivity was also criticized. Several Member States (for example, the Czech Republic, the United Kingdom, Germany, Italy and Romania) have rejected it because the measure discriminates based on farm size (Sahrbacher et al., 2015). Therefore, member states with large farms, having a significant role in the production, were more deeply affected. Besides, it had hardly any impact, for example, only EUR 109 million was collected at the EU level in 2015, 2/3 of which was withdrawn from Hungary (DG IP, 2016). Thirdly, the distribution of support was not necessarily more equitable, because smaller farms have off-farm income and the reduction of subsidies results in a less competitive agricultural structure for large farms (Matthews, 2017). Fourthly, it can be said that only 
nine Member States have capped direct payments (Austria, Belgium, Bulgaria, the United Kingdom except for England, Greece, Ireland, Poland and Italy) and most of the Member States introduced only the 5\% degressivity over 150,000 EUR (Matthews, 2018). Besides, it should not be forgotten that the effects of the measure can even be eliminated by splitting large production units into smaller ones. For this reason, the Ciolos reform has had a significant impact on the Hungarian farm structure, especially on large farms, due to the so-called dual production system of the country. This is disadvantageous for competitiveness, as large farms are undoubtedly the engines of production and growth in the European Union (Mizik, 2019).

The young farmers scheme aims to promote generation renewal in the agricultural sector. Based on Eurostat data, this is important because the proportion of 65 years or older people in the EU-28 is 2.4\%, but $9.0 \%$ in agriculture (Eurostat, 2017). There are huge differences between the member states, very high levels in Portugal (41.6\%), followed by Ireland $(21.7 \%)$ and the United Kingdom (18.6\%), while this is not a significant problem in Spain or Poland (1.8\% and 3.2\%, respectively) (Eurostat, 2017). The empirical results are mixed, although the positive effect of the measure is undeniable, its impact at the EU level is questionable, and it is worth analysing it as a part of the small-scale producer problem in the Central and Eastern Europe (Zagata \& Sutherland, 2015). Based on the scenario analysis of Bartolini and Viaggi (2013), specialised farms managed by young farmers are the most resistant to even significant changes of the CAP, however, a significant budget cut would result in an increased concentration.

The major aim of the study is to evaluate the economic impacts of the latest CAP reform. Different reform elements have had different impacts on the Hungarian farms. The basic research question of the analysis is whether the agricultural farms gave rational, economically adequate answers to these changes or not.

\section{Materials and Methods}

The basis of the article is a detailed literature review on the expected and factual effects of the Ciolos reform (more details on the CAP reforms, including this latest one, can be found in Swinnen, 2015). Based on it, different data sources are used to demonstrate these effects on Hungarian agriculture. Changes in production structure can be traced back by different datasets of the Hungarian Central Statistical Office (HCSO). The source of the support data is the Hungarian State Treasury (HST), the accredited paying agency. Labour data come from the Eurostat database. Based on these data, basic statistical calculations (averages, distribution) were used to reveal the effects of the reform on the agricultural production units. The initial hypothesis of the article is that producers gave a rational response to the analysed changes, so, they have made all efforts to get as much support as possible, as well as to comply with the regulations in the simplest possible way.

\section{Results and Discussion}

The last CAP reform took place in 2013. Its major elements were (EU, 2013):

- The basic payment is the most significant element of the reform in financial terms. Two connecting terms are degressivity $(5 \%$ obligatory reduction over 150,000 EUR direct payment per farm) and capping (an option to limit direct payments over a certain amount);

- Every member state had to allocate $30 \%$ of direct payments to greening including three simultaneous criteria - crop diversification, maintenance of permanent grasslands and ecological focus areas;

- Coupled support with production requirement with the option of coupled protein support;

- Young farmers scheme for agricultural producers below 40 years;

- Small farmers scheme provides a lump-sum payment of 500 - 1250 EUR year ${ }^{-1}$ under simplified administration.

The financial allocation of the Hungarian envelope is as follows: $53.83 \%$ basic payment, $30 \%$ greening, $13+2 \%$ coupled support, $0.62 \%$ young farmers support and $0.55 \%$ small farmers payment (Algeier, 2015). Besides the highest possible share of voluntary coupled support, the major characteristic of the Hungarian model is the maximum $(100 \%)$ capping over 176,000 EUR per individual farm (physical farm size is $1200 \mathrm{ha}$ ).

Since the basic payment is the most significant element of the national envelope (almost 54\%, or approximately 50,000 HUF per ha), only this payment is affected by the reduction and maximization. This amount is high enough, therefore the adaptation of the production units concerned was the most significant to reduce the level of withdrawal. Of course, the effects of land law change should not be overlooked. The CXXII land law (Act, 2013) in 2013 introduced the land ownership and land use limits (basically 1,200 ha and 1,800 under certain preferential conditions like livestock farms or seed producers). Based on HCSO data, the number of farmers over 2,500 ha and the total area used by them decreased by $12-13 \%$ between 2010 and 2013, but in the following 3 years their number dropped to almost half, while their utilised agricultural area (UAA) fell by 40\% (HCSO, 2016). Examining this at the level of farms receiving direct payments, the number of farms above 1,200 ha UAA 
decreased from 477 in 2012 to 259 in 2016, and, on the contrary, the number of farms with $600-1,200$ ha UAA increased from 556 to 773 in the same period (Szerletics, 2018). In practice, this means that farms that use more than 1,200 ha agricultural land started to split up to comply with the statutory requirements of the new land law and, on the other hand, not to lose their basic payment. In practice, it was an 'artificial' redistributive effect. In Italy, for example, switching from the single payment scheme to the basic payment scheme, due to the CAP 2013 reform, resulted in the decrease in the concentration of direct payments (Ciliberti \& Frascarelli, 2018).

Regarding the greening, crop diversification means a basic diversification of production income, thereby providing some protection against the possible individual, mostly weather-related effects, as the co-production of different crops reduces the chances of each being equally affected. This type of diversification increases with the size of the cultivated area, i.e. it does not cause an insoluble problem. This is the same with the obligation to maintain permanent grassland. It can only be a problem if the farmer wants to intensify his production, for example, if the livestock population is reduced and there is no longer need for the same size of grassland. However, this type of important decision is a long-term one, and will not cause any serious problems to comply with it during a 7-year period (due to the late start, it is actually a 6 -year period). The creation of ecological focus area meant some challenges, as it has certainly been a new requirement. To provide information to producers, the Hungarian Chamber of Agriculture (HCA) has developed a greening calculator that includes landscape features and other areas of ecological focus that can be used to achieve the $5 \%$ target value (HCA, 2019a). Practical experience shows that producers have moved towards the lowest resistance, e.g. the ecological focus area was typically developed within the agricultural production. According to the HST data, it can be stated that nitrogen-fixing crops, ecologically important catch crops and fallow area served this purpose, as they accounted for more than $90 \%$ of non-weighted EFA areas (FM, 2017). However, it is important to mention that, from 2018 onwards, no pesticides can be used on these areas, but it is positive that the weighting factor increased from 0.7 to 1 for areas with nitrogen-fixing crops (HCA, 2018a). However, the first one seems to be more important, which can significantly reduce the area of nitrogen-fixing crops, as the chances of pest control will be worse, which causes significant negative yield affect. At the same time, in the case of fallow areas and ecologically important catch crops, much smaller agrotechnical changes are required, so they are expected to replace nitrogen-fixing plants (HCA, 2018b). However, this effect can only be demonstrated later based on statistical data. According to the data of the HCSO, the two most important nitrogen-fixing crops in Hungary are lucerne and soybean, and their cultivation area started to grow after 2014 (HCSO, $2019 \mathrm{~b}$ and 2019c). Since there was no significant shift in the previous years, the main reasons for this were likely to be the introduction of EFA area as a part of greening and the coupled protein support, which will be analysed in the next section.

In the case of coupled payments, it is possible to pay an advance payment, which provides substantial assistance in dealing with liquidity problems. Based on the data provided by the HST, there are significant differences in the use of financial resources between the different measures. In addition to animal-related measures, the four most important plant subsidies were protein crops and protein fodder, field vegetables and fruits. Table 1 shows the advance payments and the expected amount of payments for the major measures.

Majority of the coupled supports are used in the livestock sector, especially for milk. It is worth noting

\section{Major coupled payment measures in Hungary, 2018 (HUF)}

Table 1

\begin{tabular}{|l|c|c|}
\hline Name of the measures & $\begin{array}{c}\text { Maximum of advance } \\
\text { payment }\end{array}$ & $\begin{array}{c}\text { Expected amount of } \\
\text { payment }\end{array}$ \\
\hline Coupled support for sheep & 5,621 & 8,030 \\
\hline Coupled support for suckler cow & 32,145 & 45,921 \\
\hline Coupled support for male bovine animal & 11,660 & 16,657 \\
\hline Coupled support for milk (milking cow) & 73,576 & 105,108 \\
\hline Coupled support for field vegetables & 44,794 & 63,992 \\
\hline Coupled support for fruits (extensive-traditional) & 52,185 & 74,551 \\
\hline Coupled support for fruits produced in intensive orchard & 92,633 & 132,333 \\
\hline Coupled support for protein crops & 45,612 & 65,160 \\
\hline Coupled support for protein fodder & 16,989 & 24,270 \\
\hline
\end{tabular}

Source: Author's calculation based on Annex 1 of MA (2019) and Oláh (2018). 
Number and share of agricultural employment by age groups, 2013-2017 (thousands and \%)

\begin{tabular}{|l|c|c|c|c|c|}
\hline & 2013 & 2014 & 2015 & 2016 & 2017 \\
\hline From 15 to 39 years & 66.9 & 68.6 & 74.6 & 78.4 & 77.2 \\
\hline - share in the total 15 - 39 years employment & $3.7 \%$ & $3.7 \%$ & $4.0 \%$ & $4.2 \%$ & $4.2 \%$ \\
\hline 65 years or over & 3.6 & 4.1 & 3.3 & 4.3 & 5.0 \\
\hline - share in the total 65 years or over employment & $11.0 \%$ & $13.3 \%$ & $9.5 \%$ & $10.2 \%$ & $10.4 \%$ \\
\hline
\end{tabular}

Source: Author's calculation based on Eurostat (2019) data.

that the role of subsidies in the cattle sector is crucial, the average rate of agricultural subsidy is ranging from 130 to $170 \%$ of the pre-tax profit (Czerván, 2017). For this reason, it is expected that the livestock population will grow. According to HCSO (2019c) data, it can be clearly seen as both cattle and milking cow population have increased in the past four years (2014-2017). It has a positive effect on cow milk production, which is further strengthened by an average 3\% annual increase of the milk yield (HCSO, 2019d). With regard to the crops, the highest coupled support is allocated to protein crops and protein fodder crop production. The amount of payment is higher for the former one (Table 1), but the latter is more popular in terms of area (according to the data of the HST, it was 176,106 ha in 2018, compared to 81,412 ha in 2017).

Ageing is a crucial problem of not only the Hungarian but also the European agriculture. One of the pillars of improving the age structure is the young farmers scheme. However, young farmers support is relatively small, as only $67.9 \mathrm{EUR} \mathrm{ha}^{-1}$ can be used for a period of up to 5 years for a maximum of 90 ha of UAA, and it is only for those who are not older than 40 (HCA, 2017). It can be effective in age renewal only if the agricultural production itself can generate profit. According to the data of HST, the number of recipients of payments increased from 10,031 in 2016 to 12,722 in 2017, however, the total payment decreased slightly, suggesting that new entrants into the young farmers scheme are utilising smaller areas on average. The initial effects of this scheme can be measured in the composition of the agricultural workforce. Table 2 shows the evolution and distribution of the number of people employed in agriculture by age categories. The table includes those aged 15 - 39 (eligible for young farmers support), 65 years of age and above, as well as the ratio of the respective category to the same age category in the national economy.

It can be seen from the table above that the size of the young age group in agriculture is increasing both in absolute terms and in the proportion of those aged $15-39$. However, this does not entail a similar improvement in the age structure, as the number of people aged 65 and over has also increased throughout the period, although their share (in parallel with the increase in life expectancy) decreased somewhat in proportion to the same category of the national economy (from 11.0 to $10.4 \%$ ). This is slightly above the EU-28 average of $9.0 \%$. Of course, it should not be forgotten that the number of people in this category is influenced by the difference between the number of people aged 64 in the given years (who turns to 65 next year) and those who are permanently withdrawing from the agricultural sector.

Finally, small farmers scheme can be an optimal solution for those farmers who use small UAA. According to the support calculator of the HCA, the maximum amount of payment (1250 EUR) is equivalent to direct support (basic payment + greening) for approximately 5.5 ha of land, whereas for the minimum amount of 500 EUR it equals the direct support of $2.2 \mathrm{ha}$ (HCA, 2019b). The system was only allowed to enter until 15 August 2015 to receive an annual lump-sum payment by 2020 . However, the producers had to maintain the eligible area during that period. This was particularly advantageous for those who would not have received a direct payment of 500 EUR in the standard system, as it was rounded up to this minimum. Whichever producer entered the system, they could only receive this support in 2015 and could return to the standard system by 2016 at the earliest. The farmers' decision-making process was helped not only by the HCA support calculator but also by the local agricultural consultants. The most important characteristics of this support system can be seen by using the data of HST, especially the average and the largest supported area because these two values show how rational decision was made by the producers concerned (Table 3 ).

Table 3 shows that the size of the approved area decreases as the number of supported farmers decreases. This results in a decrease in the average supported area, and the value below 2 ha in 2017 shows rational producer behaviour. In such a small area, even the minimum amount of support may result in higher revenue than what would be possible in the standard system. At the same time, it can also be seen in 2015 that at least one farmer has made a wrong decision by choosing small farmers scheme. Having 54.41 ha UAA would result in far higher support in the standard system than the maximum ceiling of 1250 EUR here. However, it can be seen from the 
Major characteristics of small farmers scheme, 2015-2017

\begin{tabular}{|l|c|c|c|}
\hline & 2015 & 2016 & 2017 \\
\hline Supported area (ha) & 109,579 & 82,725 & 59,554 \\
\hline Supported farmers (persons) & 50,000 & 39,491 & 30,847 \\
\hline Average supported area (ha) & 2.19 & 2.09 & 1.93 \\
\hline The largest supported area (ha) & 54.41 & 9.86 & 9.86 \\
\hline
\end{tabular}

Source: Author's calculation based on HST data.

table that this producer has withdrawn from the small farmers schemes in 2016 since the largest supported area dropped to 9.86 ha. Even with this UAA size, it is possible to have more support in the standard system, but on the one hand there would be no significant difference between them, and on the other hand, the lack of minimum administration and production constraints could compensate for this (for example, if the farmer does not want to maintain his permanent grassland).

However, the above data do not reveal the number of producers who chose the standard system, even though they would have been better off with the lumpsum support for small farmers. As far as the 'too large' farms are concerned, the HCA drew special attention to these producers. It is a fact that the first group contained about 6,000 farms (too small for the standard system), while the latter one (too large for the small farmers scheme) only 772 (HCA, 2015). Based on this, it is presumed that fewer farmers joined the small farmers support system, which was disadvantageous for them than who did not join, although it would have been more beneficial financially.

As the future of the CAP is expected to lead to a reduction in financial resources or a different structure, it is essential for producers to be aware of the expected changes and to take the necessary steps for adaptation as early as possible. Taking into consideration the high level of support dependency, Hungarian farmers are expected to be in a less advantageous environment without instant competitiveness actions (Mizik, 2017). Based on the results above, however, it can be clearly seen that farmers thought rationally and provided reasonable answers to the changes in the support/ regulatory system.

\section{Conclusions}

The initial hypothesis of the article is that farmers have responded rationally to the changes in the support system. Based on practical experiences, it can be clearly seen that farmers thought rationally and provided reasonable answers to the changes in the support/regulatory system. It was confirmed that some of the farms above the eligibility level have reorganized their operations into smaller production units due to degressivity and capping. The number of farms above 2,500 ha has decreased and the number of farms under 1,200 ha has increased, but the area used by large farms hardly decreased. Thus, in practice, limiting basic payment to farm size has triggered the process of splitting up farms into smaller units. The $30 \%$ share of greening was also significant enough for the producers concerned to meet the necessary conditions. All in all, diversification is the interest of the producers, for ecological focus area creation obvious agricultural solutions were used (e.g. nitrogen-fixing crops), while maintaining permanent grassland was a long-term decision. The effects of coupled supports were twofold. In crop production, most of the support was paid after the production of protein grain and protein fodder crops. In this case, farmers received not only extra support but also met the EFA requirements. In livestock production, coupled support plays a key role, as the sector's income-generating capacity is worse than that of the crop production, resulting in a much higher average rate of agricultural subsidies to the pre-tax profits. The young farmers scheme aims to improve the agricultural age structure. The number of farmers under 40 years has increased as well as their share in total employees of the same age category. At the same time, however, the number of farmers aged 65 or over has also increased. Therefore, further actions will be needed in this area. As a matter of the small farmers scheme, the average farm size is around 2 ha, so the average entrants were thus financially better.

\section{References}

1. Act (2013). 2013. évi CXXII. törvény a mező- és erdőgazdasági földek forgalmáról (Act CXXII. of 2013 on Transactions in Agricultural and Forestry Land). (in Hungarian)

2. Algeier, W. (2015). Közvetlen termelői támogatások (Direct producer payments). Magyar mezőgazdaság, 5, pp. 10-11. (in Hungarian) 
3. Alons, G. (2017). Environmental policy integration in the EU's common agricultural policy: greening or greenwashing? Journal of European Public Policy, 24(11), pp. 1604-1622.

4. Bartolini, F., \& Viaggi, D. (2017). The common agricultural policy and the determinants of changes in EU farm size. Land Use Policy, 31, pp. 126-135.

5. Ciliberti, S., \& Frascarelli, A. (2018). The CAP 2013 reform of direct payments: redistributive effects and impacts on farm income concentration in Italy. Agricultural and Food Economics, 6(1), p. 19.

6. Czerván, Gy. (2017). A szarvasmarha ágazat agrárgazdasági helyzete (The agricultural situation of the cattle sector). Presentation, Association of Hungarian Simmental, Professional Days, Kocsér, 22.06.2017. (in Hungarian)

7. DG IP (2016). Research for Agri Committee - CAP Reform Post-2020 - Challenges in Agriculture. Workshop documentation, Directorate-General for Internal Policies, Policy Department B: Structural and Cohesion Policies.

8. EC (2017). Communication from the Commission to the European Parliament, the Council, the European Economic and Social Committee and the Committee of the Regions. The Future of Food and Farming. COM(2017) 713 final, Brussels, Belgium.

9. EC (2012). The Common Agricultural Policy - A story to be continued. European Commission, Luxembourg.

10. ECA (2008). Is cross compliance an effective policy? European Court of Auditors, Special report No. 8.

11. EU (2013). Regulation of the European Parliament and of the Council establishing rules for direct payments to farmers under support schemes within the framework of the common agricultural policy and repealing Council Regulation (EC) No 637/2008 and Council Regulation (EC) No 73/2009. PE-CONS 95/13, Brussels, Belgium.

12. Eurostat (2019). Employment by sex, age and economic activity (from 2008 onwards). Retrieved March 14, 2019, from http://appsso.eurostat.ec.europa.eu/nui/show.do?dataset=lfsq_egan2\&lang=en.

13. Eurostat (2017). Farmers in the EU - statistics. Retrieved March 14, 2019, from https://ec.europa.eu/ eurostat/statistics-explained/index.php/Farmers_in_the_EU_-_statistics.

14. FM (2017). A zöldítés aktualitásai, 2018-tól alkalmazandó változásai (News in greening, applicable from 2018 onwards). Ministry of Agriculture, Budapest, Hungary. (in Hungarian)

15. Greer, A. (2017). Post-exceptional politics in agriculture: an examination of the 2013 CAP reform. Journal of European Public Policy, 24(11), pp. 1585-1603.

16. HCA (2019a). Zöldítés kalkulátor (Greening calculator). Retrieved March 13, 2019, from https://www. nak.hu/zoldites-kalkulator. (in Hungarian)

17. HCA (2019b). KAP támogatás kalkulátor (CAP direct support calculator). Retrieved March 13, 2019, from https://www.nak.hu/kapcalk. (in Hungarian)

18. HCA (2018a). Zöldítés. Gazdálkodói kézikönyv (Greening. Farmer's manual). Hungarian Chamber of Agriculture, Budapest, Hungary. (in Hungarian)

19. HCA (2018b). Zöldítés a gyakorlatban - gazdálkodói segédlet (Greening in practice - farmer's guide). Hungarian Chamber of Agriculture, Budapest, Hungary. (in Hungarian)

20. HCA (2017). Fiatal mezőgazdasági termelők támogatása (Young farmers scheme). Hungarian Chamber of Agriculture, Budapest, Hungary. (in Hungarian)

21. HCA (2015). Vidékfejlesztés (Rural development). Retrieved March 14, 2019, from http://www.nak.hu/ tamogatasok/3327-kedvezo-feltetelek-a-kistermelok-tamogatasaban-augusztus-15-ig. (in Hungarian)

22. HCSO (2019a). 4.1.1. Economic accounts for agriculture, at current basic prices (1998). Retrieved February 25, 2019, from http://www.ksh.hu/docs/eng/xstadat/xstadat_annual/i_omr002b.html.

23. HCSO (2019b). 4.1.15. Production and use of main cereals (2015). Retrieved March 14, 2019, from http:// www.ksh.hu/docs/eng/xstadat/xstadat_annual/i_omn001a.html.

24. HCSO (2019c). 4.1.16. Production and use of main crops grown on arable land (2015). Retrieved March 14, 2019, from http://www.ksh.hu/docs/eng/xstadat/xstadat_annual/i_omn002a.html.

25. HCSO (2019d). 4.1.25. Production of main animal products (1990). Retrieved March 14, 2019, from http://www.ksh.hu/docs/eng/xstadat/xstadat_annual/i_oma002.html.

26. HCSO (2016). Agrárium 2016. (Agriculture 2016) Statisztikai tükör, 2016. november 22., Hungarian Central Statistical Office, Budapest, Hungary. (in Hungarian)

27. Matthews, A. (2018). Why capping will be a mirage. Retrieved January 16, 2019, from http://capreform. eu/why-capping-will-be-a-mirage/.

28. Matthews, A. (2017). The challenges of the next CAP: doing more with less. Agriregionieuropa anno 13(50), Set 2017. 
29. Matthews, A. (2013). Greening agricultural payments in the EU's Common Agricultural Policy. Bio-based and Applied Economics, 2(1), pp. 1-27.

30. MA (2019). 31/2018. (X. 15.) AM rendelet az agrártámogatások 2018. évi mértékének megállapításáról (Ministry of Agriculture regulation 31/2018. (X. 15.) on the level of agricultural subsidies in 2018). (in Hungarian)

31. Mizik, T. (2019). A Közös Agrárpolitika üzemszintű hatásai magyar szemszögből (Farm level effects of the Common Agricultural Policy from Hungarian perspective). Gazdálkodás, 63(1), pp. 3-21. (in Hungarian)

32. Mizik, T. (2017). The past, present and future of the CAP - the Hungarian viewpoint. pp. 43-61. In: Wigier, M. - Kowalski, A. (eds.). The Common Agricultural Policy of the European Union - the present and the future: EU Member States point of view. Instytut Ekonomiki Rolnictwa i Gospodarki Zywnosciowej, Panstwowy Instytut Badawczy, Warszawa, Poland.

33. Oláh, E. (2018). A 2018. évi uniós közvetlen és átmeneti nemzeti támogatások várható alakulása (Expected evolution of EU's direct payments and temporary national supports in 2018). Retrieved March 13, 2019, from http://www.mosz.agrar.hu/ado-szamvitel-tamogatas/1586-a-2018-evi-unios-kozvetlen-es-atmenetinemzeti-tamogatasok-varhato-alakulasa. (in Hungarian)

34. Sahrbacher, A., Balmann, A., \& Sahrbacher, C. (2015). The Political Economy of Capping Direct Payments - Applications in - and implications for - Germany. pp. 277-306. In: Swinnen, J.F.M. (ed.). The Political Economy of the 2014-2020 Common Agricultural Policy. An Imperfect Storm. Rowman \& Littlefield International, Ltd., London, UK.

35. Solazzo, R., Donati, M., Tomasi, L., \& Arfini, F. (2016). How effective is greening policy in reducing GHG emissions from agriculture? Evidence from Italy. Science of the Total Environment, 573, pp. 1115-1124.

36. Swinnen, J. ed. (2015). The Political Economy of the 2014-2020 Common Agricultural Policy: An Imperfect Storm. Rowman \& Littlefield International, Ltd., London, UK.

37. Szerletics, Á. (2018). Degressivity, capping and European farm structure: New evidence from Hungary. Studies in Agricultural Economics, 120(2), pp. 80-86.

38. Zagata, L., \& Sutherland, L-A. (2015). Deconstructing the 'young farmer problem in Europe': Towards a research agenda. Journal of Rural Studies, 38(2), pp. 39-51. 